Article

\title{
Chemical Composition and In Vitro Cytotoxic and Antimicrobial Activities of the Essential Oil from Leaves of Zanthoxylum monogynum St. Hill (Rutaceae)
}

\author{
Fernanda B. da Silva ${ }^{1}$, Nara O. dos Santos ${ }^{2}$, Renata C. Pascon ${ }^{2}$, Marcelo A. Vallim ${ }^{2}$, \\ Carlos R. Figueiredo ${ }^{3}$, Roberto C. Campos Martins ${ }^{1}$ and Patricia Sartorelli ${ }^{2, *}$ \\ 1 Instituto de Pesquisas de Produtos Naturais Walter Mors, Universidade Federal do Rio de Janeiro, \\ Rio de Janeiro 21941-902, RJ, Brazil; silvanandab@gmail.com (F.B.d.S.); roberto@nppn.ufrj.br (R.C.C.M.) \\ 2 Instituto de Ciências Ambientais, Químicas e Farmacêuticas, Universidade Federal de São Paulo, \\ Diadema 09972-270, SP, Brazil; nara.oshiro@gmail.com (N.O.d.S.); renata.pascon@gmail.com (R.C.P.); \\ marcelo.vallim@gmail.com (M.A.V.) \\ 3 Disciplina de Biologia Celular, Departamento de Micro, Imuno e Parasitologia, \\ Universidade Federal de São Paulo, São Paulo 04023-062, SP, Brazil; rogernty@hotmail.com \\ * Correspondence: psartorelli@unifesp.br; Tel.: +55-11-3385-3473
}

Academic Editor: Eleni Skaltsa

Received: 21 March 2017; Accepted: 15 May 2017; Published: 19 May 2017

\begin{abstract}
Background: The Zanthoxylum monogynum species belongs to the family Rutaceae and is found in Southeast, Midwest, and Northeast Brazil. For this genus several biological activities have been described. Methods: The essential oil (EO) was obtained from the leaves of Zanthoxylum monogynum by hydro-distillation and was analyzed by gas chromatograph and gas chromatograph/mass spectrometry (GC and GC/MS). Also the EO of Z. monogynum was evaluated for in vitro cytotoxic activity against six tumor cell lines and for antimicrobial activity, performing disk diffusion and MIC assays with yeast and bacterial strains. Results: The chemical analysis afforded the identification of 18 components ( $99.0 \%$ of the EO). The major components were found to be citronellol $(43.0 \%)$ and farnesol $(32.0 \%)$. The in vitro cytotoxic activity against tumor cell lines, resulted in $\mathrm{IC}_{50}$ values ranging from $11-65 \mu \mathrm{g} / \mathrm{mL}$ against all tested cell lines. Antimicrobial activity of the essential oil was also tested and oil was effective, especially against Cryptococcus sp. yeast. All the tested yeast strains showed at least $90 \%$ growth inhibition. Conclusions: the essential oil from leaves of Z. monogynum has a different qualitative and quantitative composition when compared to the composition previously described. Also this EO has significant cytotoxic activity and moderate activity against Cryptococcus sp. and Saccharomyces cereviseae yeasts.
\end{abstract}

Keywords: Zanthoxylum monogynum; Rutaceae; essential oil; cytotoxic activity; antimicrobial activity

\section{Introduction}

The Rutaceae family has approximately 150 genera distributed worldwide in tropical, subtropical, and temperate regions. The Zanthoxylum genus comprises more than 200 species, being the most abundant genus in Rutaceae regarding to the number of species. In Zanthoxylum genus, it is common to find secondary metabolites such as alkaloids, lignans, coumarins, amides, flavonoids, and triterpenes $[1,2]$.

In the Zanthoxylum genus, several biological activities-larvicidal [3], trypanocidal [4], anti-tumor [5], anti-psoriasis [6], and anti-inflammatory [7], among others-have been described. In Brazil, people of the state of Rondônia use the tea from leaves and roots of Zanthoxylium sp. to relieve toothache [8]. Additionally, the species Z. simullans and Z. chalybeum are used for the treatment of malaria $[9,10]$. 
Essential oils of various species of Zanthoxylum genus, such as the essential oil from branches of Z. armantum, which presented strong insecticidal activity against pests that attack stored products [11], have had their activities tested. Essential oil from the seeds of the same species has larvicidal activity against Aedes aegypti, Anopheles stephensi, and Culex quinquefasciatus, mosquitoes that are vectors of diseases [3].

The essential oil of Z. gilletti leaves showed larvicidal activity against Anopheles gambiae, the mosquito vector of malaria in Africa [12]. It has also been found that the essential oil Z. alatum exhibits antifungal and antibacterial activity [13], and the essential oil of Z. simulans exhibits anthelmintic activity [14]. The methanolic extract and the essential oil from fruits of Zanthoxylum zanthoxyloides and Zanthoxylum leprieurii presented anti-cancer and anti-microbial properties in vitro assays [15].

Zanthoxylum monogynum is popularly known as laranjeira-do-mato, tinguaciba-da-restinga, tinguaciba, limão-bravo, or limãozinho, occurring in Brazil in the states of Alagoas, Espírito Santo, Goiás, Minas Gerais, Pernambuco, Rio de Janeiro, and São Paulo [16]. The study of Maia and Andrade [17] in 2007, with leaves of Z. monogynum collected in different regions of Brazil, gave rise to two essential oils with different compositions and characteristics.

To date, there are no data in the literature about biological activities of the essential oil of Z. monogynum. The purpose of this study was (i) to give a chemical characterization of Z. monogynum essential oil, (ii) to investigate its cytotoxic activity in vitro against six tumor cell lines (B16F10, MCF-7, A2058, HeLa, HL-60 and T75), and (iii) to determine the antimicrobial effect of Z. monogynum essential oil against yeast (Candida dubliniensis, Candida tropicalis, Candida glabrata, Candida parapsilosis, Candida krusei, Candida albicans, Cryptococcus grubii (Serotype A), Cryptococcus gattii (Serotype B), Cryptococcus gattii (Serotype C), Cryptococcus neoformans (Serotype D), Saccharomyces cerevisiae), and Gram-positive and Gram-negative bacterial strains (Escherichia coli, Serratia marcescens, Pseudomonas aeruginosa, Staphylococcus epidermidis, and Enterococcus faecalis).

\section{Materials and Methods}

\subsection{Plant Material}

The plant material was collected in May 2013 in Itatiaia National Park, State of Rio de Janeiro. The species was identified by Dr. Marcelo Trovó (IB-UFRJ) and a voucher specimen is registered under the number MLO 601 (RB) in the herbarium (RBA) of the Federal University of Rio de Janeiro. The fresh leaves of Z. monogynum (185 g) were used to obtain the essential oil by a hydro-distillation process for $2 \mathrm{~h}$ at $80^{\circ} \mathrm{C}$; the residual water was removed through the addition of anhydrous sodium sulfate, which was then properly removed by a filtration procedure. An aliquot of the obtained essential oil was used for GC and GC/MS analysis.

\subsection{Analysis of Essential Oil}

The oil was analyzed by GC (Shimadzu®, Kyoto, Japan) on a gas chromatograph Shimadzu GC 2010 Plus (FID detector) (Shimadzu®, Kyoto, Japan) equipped with a DB-5 column $(30 \mathrm{~m} \times 0.25 \mathrm{~mm} \times 0.25 \mu \mathrm{m})\left(\right.$ Agilent ${ }^{\circledR} \mathrm{J} \& W$ GC Columns, Santa Clara, CA, USA). GC-MS analysis were performed on a mass spectrometer GCMS-QP2010 (Shimadzu®, Kyoto, Japan) at 70 eV with a DB-5 column (same as above). Oven temperature programmed from $60{ }^{\circ} \mathrm{C}$ to $246{ }^{\circ} \mathrm{C}$ at $3{ }^{\circ} \mathrm{C} \mathrm{min}-1$. For the injection (split 1:20), $5.0 \mu \mathrm{L}$ of the essential oil were diluted in $500.0 \mu \mathrm{L}$ of dichloromethane, and $1.0 \mu \mathrm{L}$ of this diluted solution was injected. Identification of volatile constituents was made on the basis of their Kovats indexes (K.I.) and their mass spectra, which were compared with reference data [18].

\subsection{Cell Lines}

The following cell lines were obtained from the Ludwig Institute for Cancer Research (São Paulo, Brazil): human melanoma (A2058), human leukemia (HL-60), and human breast cancer (MCF-7). The human fibroblast T75, human cervical carcinoma (HeLa) cell, and the melanotic (B16F10) cell line, 
characterized by its low immunogenicity and moderate virulence, were obtained from the Experimental Oncology Unit (UNIFESP-Federal University of São Paulo, São Paulo, SP, Brazil). All tumorigenic cells were cultured in complete RPMI-1640 medium (Gibco, Grand Island, NY, USA) supplemented with $10 \%$ fetal bovine serum (FBS) (Gibco, Grand Island, NY, USA), 10 mM N-2-hydroxyethylpiperazine-N2 ethanesulphonic acid (HEPES; Sigma-Aldrich, St. Louis, MO, USA), 24 mM sodium bicarbonate, $40 \mathrm{mg} / \mathrm{L}$ gentamicin (Hipolabor, Minas Gerais, Brazil), at $\mathrm{pH} 7.2$, and $37^{\circ} \mathrm{C}$ in a humidified atmosphere with 5\% $\mathrm{CO}_{2}$. Human T75 fibroblast was cultured in complete DEMEM medium (Gibco, Grand Island, NY, USA) supplemented with $10 \%$ of FBS and $40 \mathrm{mg} / \mathrm{L}$ gentamicin. All adherent cell lines were detached from the flask by using a PBS/EDTA solution (0.02\% EDTA in PBS) and subcultured for 3-5 days until achieve $80 \%$ of max confluence or prior to be used in cytotoxic assays in vitro.

\subsection{In Vitro Cytotoxic Activity}

The essential oil from Zanthoxylum monogynum leaves was dissolved in dimethyl sulfoxide (DMSO) to a final concentration of $10.0 \mathrm{mg} / \mathrm{mL}$, diluted in RPMI medium containing $10 \%$ fetal calf serum ranging from 100.0 to $0 \mu \mathrm{g} / \mathrm{mL}$ and incubated with $1 \times 10^{4}$ cells in a 96-well plate (Corning, New York, NY, USA). After $18 \mathrm{~h}$ of incubation, cell viability was measured using the Cell Proliferation Kit I (MTT) (Sigma, Gillingham, UK), an MTT-based colorimetric assay [19]. Readings were made in a plate reader at $570 \mathrm{~nm}$. All experiments were performed in triplicates.

\subsection{Media, Antibiotics, and Growth Conditions}

Yeasts were cultivated on agar plates containing Yeast Peptone Dextrose (YPD) (1\% yeast extract, $2 \%$ peptone, $2 \%$ dextrose, and 2\% agar) or RPMI 1640 (Sigma, Saint Louis, MO, USA). Gram-negative bacteria were grown in Luria Bertani (LB) $(0.5 \%$ yeast extract, $1 \%$ tryptone, $1 \% \mathrm{NaCl}$, and $2 \%$ agar) and Gram-positive bacteria were tested in Brain Heart Infusion (BHI) (Himedia, Mumbai, India). Fluconazole (Sigma, Saint Louis, MO, USA) was used as positive controls for yeast and chloramphenicol (Sigma, Saint Louis, MO, USA) was the positive control for bacteria. Crude essential oil from Z. monogynum was diluted in DMSO or saline (0.9\%) plus Tween $80(0.5 \%)$ and spotted on $5 \mathrm{~mm}$ sterile filter paper [20].

\subsection{Microorganisms Strain}

The bacteria and yeast species used in this work are described in Table 1. These strains where obtained from CBMAI (Coleção Brasileira de Micro-organismos de Ambiente e Indústria) and ATCC (American Type Culture Collection).

\subsection{Disk Diffusion Assay}

To assess the antimicrobial activity of Z. monogynum essential oil, the disk diffusion method described by the Clinical and Laboratory Standards Institute (CLSI, OPAS M2-A8) was used with some modification. Thin agar plates with $10 \mathrm{~mL}$ of either YPD (yeast) or LB (Gram-negative) or BHI (Gram-positive) media supplemented with $2 \%$ agar were covered with $10 \mathrm{~mL}$ of soft agar medium (YPD, LB, or BHI plus $1 \%$ agar) containing $100 \mu \mathrm{L}$ of each fresh culture (adjusted to $\mathrm{OD}_{600}=0.3$ ) of yeast or bacteria grown for $12-16 \mathrm{~h}$ in $3 \mathrm{~mL}$ of liquid media incubated at $30^{\circ} \mathrm{C} / 37^{\circ} \mathrm{C}$ with aeration (150 rpm). After the agar was solidified, $5 \mathrm{~mm}$ filter paper disks sterilized and impregnated with $20 \mu \mathrm{L}$ of crude essential oil diluted in DMSO were placed on top of agar plates and incubated at $30^{\circ} \mathrm{C} / 37^{\circ} \mathrm{C}$ for 24 or $48 \mathrm{~h}$ depending on the microorganism. Fluconazole $(1 \mathrm{mg})$ and chloramphenicol $(200 \mu \mathrm{g})$ impregnated disks were used as positive controls for yeast and bacteria, respectively. Negative control was prepared by paper disks impregnating with DMSO at the same concentration employed to dilute the essential oil. All tests were performed in duplicates. Tested strains were selected based on their clinical importance and previous results obtained by our research group [20]. 
Table 1. Target strains used for antimicrobial activity assays.

\begin{tabular}{cc}
\hline Species & Designation \\
\hline Yeast & \\
\hline Candida dubliniensis & ATCC 7978 \\
Candida tropicalis & ATCC 13803 \\
Candida glabrata & ATCC 90030 \\
Candida parapsilosis & Clinical isolate 68 \\
Candida krusei & Clinical isolate 9602 \\
Candida albicans & CBMAI 560 \\
Cryptococcus grubii (A) & ATCC 208821 \\
Cryptococcus gattii (B) & ATCC MYA-4563 \\
Cryptococcus gattii (C) & ATCC MYA-4560 \\
Cryptococcus neoformans (D) & ATCC MYA-4567 \\
Saccharomyces cerevisiae & ATCC 201389 \\
\hline Bacteria & \\
\hline Escherichia coli & CBMAI 469 \\
Serratia marcescens & CBMAI 602 \\
Pseudomonas aeruginosa & CBMAI 604 \\
Staphylococcus epidermidis & - \\
Enterococcus faecalis &
\end{tabular}

\subsection{Minimum Inhibitory Concentration}

Microdilution tests were conducted according to the Clinical and Laboratory Standards Institute (CLSI), OPAS1 M27-A2 for yeasts and OPAS M7-A6 for bacteria according to literature [20] with slight modifications. Briefly, MIC values were determined using micro titer plates ( 96 wells) in a total volume of $100.0 \mu \mathrm{L}$. Microorganisms were cultured in test tubes filled with $3 \mathrm{~mL}$ of medium (RPMI 1640 for yeast and BHI for bacteria) overnight at $30^{\circ} \mathrm{C}$ in a rotary shaker (150 rpm). The cultures were diluted and adjusted to $1-2 \times 10^{2} \mathrm{CFU} / \mathrm{mL}$ using a McFarland's scale. The CFU counts and viability was confirmed by viability counts on YPD and BHI plates (100.0 $\mu \mathrm{L}$ of diluted cells). Crude essential oil and reference standards were serial diluted (two-fold) and added to each well. A negative control containing medium only and growth control containing cell, DMSO $(10.0 \mu \mathrm{L})$, or saline $(10.0 \mu \mathrm{L})$ and Tween 80 were included as negative and positive controls, respectively. Depending on the microorganism, the micro titer plates were then incubated at $30^{\circ} \mathrm{C}$ for 24 or $48 \mathrm{~h}$. Microorganism growth was determined by reading the absorbance at $530 \mathrm{~nm}$ in a plate reader (Logen, MT-960, BioTek Instruments, Winooski, VT, USA), and the minimum inhibitory concentration was considered the lowest concentration at which at least $80 \%$ of growth was inhibited. All tests were performed in triplicate.

\section{Results and Discussion}

\subsection{Chemical Composition of the Essential Oil from Z. monogynum Leaves}

The hydrodistillation of the $185.0 \mathrm{~g}$ of leaves resulted in $1.1 \mathrm{~g}$ of essential oil. Analysis by gas chromatography with flame ionization detector (GC/FID) and chromatography coupled to mass spectrometry (GC/MS) and calculation of Kovats indexes and comparison with the literature data [18] allowed for the identification of 18 compounds (Table 2), which represents $99.06 \%$ of the oil. The major compound is citronellol (43.03\%), a monoterpenoid that is followed by the sesquiterpenoid farnesol (31.96\%). Another monoterpenoid, citronellal (9.57\%), was identified followed by D-germacrene $(4.52 \%), \beta$-pinene $(2.02 \%), \delta$-elemene $(1.38 \%)$, and $(Z)-\beta$-farnesene $(1.20 \%)$. Together, these seven compounds correspond to $93.68 \%$ of the oil composition. 
Table 2. Chemical composition of the essential oil of Z. monogynum.

\begin{tabular}{ccccc}
\hline KI & RT (min) & Compound & Molecular Weight & $\%$ \\
\hline 855 & 2.825 & 2-hexenal & 98 & 0.20 \\
939 & 4.117 & $\alpha$-pinene & 136 & 0.99 \\
971 & 4.967 & $\beta$-tujeno & 136 & 0.41 \\
979 & 5.100 & $\beta$-pinene & 136 & 2.02 \\
990 & 5.350 & $\beta$-myrcene & 136 & 0.30 \\
1002 & 5.817 & $\alpha$-phellandrene & 136 & 0.17 \\
1029 & 6.442 & D-limonene & 136 & 0.90 \\
1037 & 6.950 & $\alpha$-ocimene & 136 & 0.42 \\
1082 & 8.708 & $\beta$-linalool & 154 & 0.52 \\
1153 & 10.600 & citronellal & 154 & 9.57 \\
1225 & 13.550 & citronellol & 156 & 43.03 \\
1257 & 14.663 & methyl citronelate & 184 & 0.45 \\
1338 & 17.467 & -elemene & 204 & 1.38 \\
1352 & 18.258 & citronellol acetate & 198 & 0.25 \\
1442 & 22.158 & (Z)- $\beta$-farnesene & 204 & 1.20 \\
1481 & 22.975 & D-germacrene & 204 & 4.52 \\
1436 & 25.775 & $\gamma$-elemene & 204 & 0.77 \\
1743 & 31.717 & farnesol & 222 & 31.96 \\
\hline \multicolumn{5}{c}{ Total } \\
\hline
\end{tabular}

In the study performed by Maia and Andrade in 2007 [17] with the essential oil of Z. monogynum, from different regions, the composition of each of them is described: In one of the major compounds was the oils citronellal (57.1\%), limonene (13.8\%), citronellyl acetate $(13.1 \%)$, and citronellol $(6.2 \%)$. In the other, the main compounds were 2-undecanone (70.2\%) and citronellal (22.5\%). It is believed that this difference in composition might be related to the use of leaves from two chemotypes of Zanthoxylum monogynum. Additionally, some factors can affect this difference in composition such as geographical locations, environment, and stage of maturity [21].

\subsection{Citotoxic Activity}

The essential oil from the leaves of Z. monogynum was evaluated for its cytotoxic activity in vitro against six tumor cell lines (B16F10, MCF-7, A2058, HeLa, HL-60, and T75). The crude oil displayed activity against all cell lines tested, with $\mathrm{IC}_{50}$ values ranging from 11.0 to $65.0 \mu \mathrm{g} / \mathrm{mL}$, HL60 being the most sensitive cell line to the crude oil, with an $\mathrm{IC}_{50}$ of $11.0 \mu \mathrm{g} / \mathrm{mL}$, followed by A2058 with an $\mathrm{IC}_{50}$ value of 34.0. Other tumor cell lines BF16F10, MCF-7, and HeLa were less sensitive with $\mathrm{IC}_{50}$ values of $60.0,65.0$, and 62.0 respectively (Table 3 ).

Table 3. $\mathrm{IC}_{50}(\mu \mathrm{g} / \mathrm{mL})$ values to essential oil from Z. monogynum leaves and to positive controls (cisplatin and paclitaxel) against tumor cell lines.

\begin{tabular}{cccc}
\hline \multirow{2}{*}{ Cell Lines } & \multicolumn{3}{c}{ IC $_{\mathbf{5 0}}(\boldsymbol{\mu g} / \mathbf{m L})$} \\
\cline { 2 - 4 } & Essential Oil & Cisplatin & Paclitaxel \\
\hline B16F10 & $60.0 \pm 8.9$ & $52.8 \pm 4.50$ & - \\
A2058 & $34.0 \pm 8$ & $43.1 \pm 3.6$ & - \\
MCF-7 & $65.7 \pm 2.8$ & - & $171.5 \pm 16.39$ \\
HeLa & $62 \pm 5.9$ & $20.3 \pm 1.20$ & - \\
HL-60 & $11.0 \pm 1$ & $20.9 \pm 1.50$ & - \\
T75 & $60 \pm 4$ & nd & nd \\
\hline
\end{tabular}

nd, not determined; -, not evaluated.

In a previous study concerning the cytotoxic activity of essential oil of another species of Zathoxylum (Z. fagara), whose major constituent was citronellol (26\%), was evaluated against MDAMB-231 (human breast adenocarcinoma), Hs 578T (human breast ductal carcinoma), and 5637 
(human primary bladdercarcinoma) cells. Neither the essential oil itself nor its major compounds exhibited notable cytotoxic activity against these cell lines [22].

However, the effects of essential oils have been investigated against diverse tumor cells such as glioblastoma, melanoma, leukemia, and oral cancers, as well as colon, kidney, and others [23]. Additionally essential oils from Casearia sylvestris [24] and Lippia alba [25] have been described as cytotoxic against melanoma murine (BF16F10). Furthermore, several essential oils could have anticancer effects, as there is a relationship between the production of reactive oxygen species and the origin of oxidation and inflammation that can lead to cancer [23].

The results presented here, where the essential oil from Z. monogynum showed similar or lower $\mathrm{IC}_{50}$ values (in the case of MCF-7 and HL-60 cell lines) in comparison to standard drugs (cisplatin and paclitaxel) against the tested cells, suggest that it could be further explored as a source for compounds with antitumor activity. Thus, the essential oil from Z. monogynum could be considered as a source of antitumor compounds.

\subsection{Antimicrobial Activity}

Regarding antimicrobial activity, initially, disk diffusion assays were conducted with the yeasts and bacterial strains listed in Table 1 in order to screen for antimicrobial activity. No bacterial strains were sensitive to essential oil from Z. monogynum, but the crude oil was sensitive to yeast, especially Cryptococcus sp. (Supplementary Table S1). Since no biological activity was detected for bacterial strain in this qualitative assay, no further experiments were conducted with these microorganisms. However, the MIC test applied to the yeast species listed in Table 1 confirmed that all yeast strains were sensitive to essential oil at concentrations ranging from 0.75 (S. cerevisae) to $6.0 \mathrm{mg} / \mathrm{mL}$ (Candida sp.) with $90 \%$ growth inhibition (Table 4).

Table 4. Minimum inhibitory concentrations (MICs) for Z. monogynum essential oil and positive control (fluconazole) both expressed in $\mathrm{mg} / \mathrm{mL}$. Numbers in parenthesis represent the average percentage inhibition for each MIC followed by the standard deviation.

\begin{tabular}{ccc}
\hline Species & OEZM $(\mathbf{m g} / \mathbf{m L})$ & Fluconazol (mg/mL) \\
\hline Candida albicans & $3.0(99.44 \% \pm 0.03)$ & $0.025(98.41 \% \pm 0.21)$ \\
C. dubliniensis & $3.0(95.65 \% \pm 4.05)$ & $0.013(99.47 \% \pm 0.07)$ \\
C. tropicalis & $3.0(99.23 \% \pm 0.16)$ & $0.05(93.59 \% \pm 0.46)$ \\
C. glabrata & $6.0(97.78 \% \pm 0.59)$ & $0.05(94.49 \% \pm 8.22)$ \\
C. parapsilosis & $6.0(98.78 \% \pm 0.21)$ & $0.025(86.27 \% \pm 3.27)$ \\
C. krusei & $6.0(98.84 \% \pm 0.78)$ & $0.05(85.34 \% \pm 6.67)$ \\
Cryptococcus neoformans var. grubii (sorotipo A) & $1.5(92.12 \% \pm 0.39)$ & $0.025(92.82 \% \pm 0.38)$ \\
C. neoformans var. gattii (sorotipo B) & $1.5(95.26 \% \pm 0.67)$ & $0.013(98.84 \% \pm 0.05)$ \\
C. neoformans var. gattii (sorotipo C) & $1.5(92.47 \% \pm 0.76)$ & $0.013(98.05 \% \pm 0.12))$ \\
C. neoformans var. neoformans (sorotipo D) & $1.5(91.96 \% \pm 0.62)$ & $0.025(99.54 \% \pm 0.65)$ \\
Saccharomyces cerevisiae & $0.75(94.54 \% \pm 0.90)$ & $0.025(91.94 \% \pm 0.04)$ \\
\hline
\end{tabular}

Several essential oils and their major constituents from medicinal plants have been reported to possess a wide range of bacterial and fungal inhibitory potentials [26,27]. Additionally, citronellol has been described as active against Candida tropicalis [28]. However, the selectivity index $\left(\mathrm{SI}_{50}=\mathrm{IC}_{50} / \mathrm{MIC}\right)$ estimated for this essential oil is low, meaning that it may have low selective toxicity. In the future, this matter could be overcome by chemical modifications in the inhibitor.

\section{Conclusions}

According to the results, the essential oil from leaves of Z. monogynum has a different qualitative and quantitative composition when compared to the composition previously described, showing sesquiterpenes citronellol and farnesol as major constituents. Lower $\mathrm{IC}_{50}$ values for the tested tumor cell lines proved that this EO has significant cytotoxic activity. EO from Z. monogynum has also 
proven to exhibit moderate activity against Cryptococcus sp. and Saccharomyces cereviseae yeasts, but not significant activity against Candida bacterial strains. Analysis of the EO composition suggests that the major compounds might not be responsible for the observed activities as citronellol itself was previously tested against Candida tropicalis and showed to be potent against this bacterium.

Supplementary Materials: The following are available online at www.mdpi.com/2305-6320/4/2/31/s1, Table S1: Inhibition zone (IZ) expressed in centimeters $(\mathrm{cm})$ produced by the positive control $(1 \mathrm{mg}$ of chloranphenicol for bacteria and $200 \mu \mathrm{g}$ of fluconazole for yeast strains) and OEZM.

Acknowledgments: The authors wish to thank to Fundação de Amparo à Pesquisa do Estado de São Paulo (FAPESP) (2016/24985-4) and Conselho Nacional de Desenvolvimento Científico e Tecnológico (CNPq) for providing financial support to this study. FBS and NOdS obtained a fellowship from Coordenação de Aperfeiçoamento de Pessoal de Nivel Superior (CAPES). PS received a scientific research award from CNPq.

Author Contributions: F.B.d.S., N.O.d.S., R.C.P., M.A.V., C.R.F. performed the experiments, contributed reagents / materials / analysis tools and wrote the manuscript. R.C.C.M. and P.S. conceived and designed the project, analyzed the results and wrote the manuscript.

Conflicts of Interest: The authors declare no conflict of interest.

\section{Abbreviations}

The following abbreviations are used in this manuscript:

GC gas chromatograph

GC/MS gas chromatograph/ mass spectrometry

K.I. Kovats Index

R.T. Retention Time

OEZM essential oil of Zanthoxylum monogynum

MIC Minimum Inhibitory Concentration

IB-UFRJ Institute of Biology-Federal University of Rio de Janeiro

DMSO dimethyl sulfoxide

\section{References}

1. Moccelini, S.K.; Silva, V.C.; Ndiaye, E.A.; Sousa, P.T., Jr.; Vieira, P.C. Estudo fitoquímico das cascas das raízes de Zanthoxylum rigidum Humb. \& Bonpl.Ex Willd (Rutaceae). Quim. Nova 2009, 32, 131-133.

2. Facundo, V.A.; Silveira, A.S.P.; Filho, R.B.; Pinto, A.C.; Rezende, C.M. Constituintes químicos de Zanthoxylum ekmanii (urb.) Alain. Quim. Nova 2005, 28, 224-225. [CrossRef]

3. Tiwary, M.; Naik, S.N.; Tewary, D.K.; Mittal, P.K.; Yadav, S. Chemical composition and larvicidal activities of the essential oil of Zanthoxylum armatum DC (Rutaceae) against three mosquito vectors. J. Vector Borne Dis. 2007, 44, 198-204. [PubMed]

4. Bastos, J.K.; Albuquerque, S.; Silva, M.L. Evaluation of the trypanocidal activity of lignans isolated from the leaves of Zanthoxylum naranjillo. Planta Med. 1999, 65, 541-544. [CrossRef] [PubMed]

5. Cao, X.L.; Xu, J.; Bai, G.; Zhang, H.; Liu, Y.; Xiang, J.F.; Tang, Y.L. Isolation of anti-tumor compounds from the stem bark of Zanthoxylum ailanthoides Sieb. \& Zucc. by silica gel column and counter-current chromatography. J. Chromatogr. B Anal. Technol. Biomed. Life Sci. 2013, 929, 6-10.

6. Li, K.; Zhou, R.; Wang, J.W.; Li, Z.; Li, J.; Zhang, P.; Xiao, T. Zanthoxylum bungeanum essential oil induces apoptosis of HaCaT human keratinocytes. J. Ethnopharmacol. 2016, 186, 351-361. [CrossRef] [PubMed]

7. Lima, L.M.; Perazzo, F.F.; Tavares Carvalho, J.C.; Bastos, J.K. Anti-inflammatory and analgesic activities of the ethanolic extracts from Zanthoxylum riedelianum (Rutaceae) leaves and stem bark. J. Pharm. Pharmacol. 2007, 59, 1151-1158. [CrossRef] [PubMed]

8. Tsunozaki, M.; Lennertz, R.C.; Vilceanu, D.; Katta, S.; Stucky, C.L.; Bautista, D.M. A 'toothache tree' alkylamide inhibits A $\delta$ mechanonociceptors to alleviate mechanical pain. J. Physiol. 2013, 591, 3325-3340. [CrossRef] [PubMed]

9. Wang, C.; Wan, J.; Mei, Z.; Yang, X. Acridone alkaloids with cytotoxic and antimalarial activities from Zanthoxylum simullans Hance. Pharmacogn. Mag. 2014, 10, 73-76. [PubMed] 
10. Bbosa, S.G.; Mwebaza, N.; Lubega, A.; Musisi, N.; Kyegombe, B.D.; Ntale, M. Antiplasmodial activity of leaf extracts of Zanthoxylum chalybeum. Br. J. Pharm. Res. 2014, 4, 705-713. [CrossRef]

11. Wang, C.; Zhang, W.; You, C.; Guo, S.; Geng, Z.; Fan, L.; Du, S.; Deng, Z.; Wang, Y. Insecticidal constituents of essential oil derived from Zanthoxylum armatum against two stored-product insects. J. Oleo Sci. 2015, 64, 861-868. [CrossRef] [PubMed]

12. Japheth, O.O.; Josphat, M.C.; John, V.M. Chemical composition and larvicidal activity of Zanthoxylum gilletti essential oil against Anopheles gambiae. Afr. J. Biotechnol. 2014, 13, 2175-2180.

13. Guleria, S.; Tiku, A.K.; Koul, A.; Gupta, S.; Singh, G.; Razdan, V.K. Antioxidant and antimicrobial properties of the essential oil and extracts of Zanthoxylum alatum grown in North-Western Himalaya. Sci. World J. 2013, 2013, 790580. [CrossRef] [PubMed]

14. Qi, H.; Wang, W.X.; Dai, J.L.; Zhu, L. In vitro anthelmintic activity of Zanthoxylum simullans essential oil against Haemonchus contortus. Vet. Parasitol. 2015, 211, 223-227. [CrossRef] [PubMed]

15. Misra, L.N.; Vyry Wouatsa, N.A.; Kumar, S.; Kumar, R.V.; Tchoumbougnang, F. Antibacterial, cytotoxic activities and chemical composition of fruits of two Cameroonian Zanthoxylum species. J. Ethnopharmacol. 2013, 148, 74-80. [CrossRef] [PubMed]

16. Melo, M.F.F.; Zickel, C.S. Os gêneros Zanthoxylum L. e Esenbeckia Kunth (Rutaceae) no estado de Pernambuco, Brasil. Acta Bot. Bras. 2004, 18, 73-90. [CrossRef]

17. Maia, J.G.S.; Andrade, E.H.A. Leaf essential oil composition of Zanthoxylum monogynum St.-Hill. J. Essent. Oil Bear. Plants 2007, 10, 282-286. [CrossRef]

18. Adams, R.P. Identification of Essential Oil Components by Gas Chromatography/Mass Spectrometry, 4th ed.; Allured Publishing: Illinois, IL, USA, 2007.

19. Mosmann, T. Rapid colorimetric assay for cellular growth and survival: Application to proliferation and cytotoxicity assays. J. Immunol. Methods 1983, 65, 55-63. [CrossRef]

20. Santos, N.O.; Mariane, B.; Lago, J.H.G.; Sartorelli, P.; Rosa, W.; Soares, M.G.; da Silva, A.M.; Lorenzi, H.; Vallim, M.A.; Pascon, R.C.; et al. Assessing the chemical composition and antimicrobial activity of essential oils from Brazilian plants-Eremanthus erythropappus (Asteraceae), Plectrantuns barbatus, and P. amboinicus (Lamiaceae). Molecules 2015, 20, 8440-8452. [CrossRef] [PubMed]

21. Swamy, M.K.; Sinniah, U.R.; Akhtar, M.S. In Vitro Pharmacological Activities and GC-MS Analysis of Different Solvent Extracts of Lantana camara Leaves Collected from Tropical Region of Malaysia. Evid.-Based Complement. Altern. Med. 2015, 2015, 506413. [CrossRef] [PubMed]

22. Setzer, W.N.; Schmidt, J.M.; Eiter, L.C.; Haber, W.A. The Leaf Oil Composition of Zanthoxylum fagara (L.) Sarg. From Monteverde, Costa Rica, and its Biological Activities. J. Essent. Oil Res. 2005, 17, 333-335. [CrossRef]

23. Bayala, B.; Bassole, I.H.N.; Scifo, R.; Gnoula, C.; Morel, L.; Lobaccaro, J.A.; Simpore, J. Anticancer activity of essential oils and their chemical components-A review. Am. J. Cancer Res. 2014, 4, 591-607. [PubMed]

24. Bou, D.D.; Lago, J.H.G.; Figueiredo, C.R.; Matsuo, A.L.; Guadagnin, R.C.; Soares, M.G.; Sartorelli, P. Cytotoxicity evaluation of essential oil, zingiberene and derivatives from leaves of Casearia sylvestris (Salicaceae). Molecules 2013, 18, 9477-9487. [CrossRef] [PubMed]

25. Santos, N.O.; Pascon, R.C.; Vallim, M.A.; Figueiredo, C.R.; Soares, M.G.; Lago, J.H.G.; Sartorelli, P. Cytotoxic and antimicrobial constituents from the essential oil from Lippia alba (Verbenaceae). Medicines 2016, 3, $22-30$. [CrossRef]

26. Swamy, M.K.; Akhtar, M.S.; Sinniah, U.R. Antimicrobial Properties of Plant Essential Oils against Human Pathogens and Their Mode of Action: An Updated Review. Evid.-Based Complement. Altern. Med. 2016, 2016, 3012462. [CrossRef] [PubMed]

27. Hammer, K.A.; Carson, C.F.; Riley, T.V. Antimicrobial activity of essential oils and other plant extracts. J. Appl. Microbiol. 1999, 86, 985-990. [CrossRef] [PubMed]

28. Souza, C.M.C.; Pereira, S.A., Jr.; Moraes, T.S.; Damasceno, J.L.; Mendes, S.A.; Dias, H.J.; Stefani, R.; Tavares, D.C.; Martins, C.H.G.; Crotti, A.E.M.; et al. Antifungal activity of plant-derived essential oils on Candida tropicalis plank tonic and biofilms cells. Med. Mycol. 2016, 54, 515-523. [CrossRef] [PubMed]

(C) 2017 by the authors. Licensee MDPI, Basel, Switzerland. This article is an open access article distributed under the terms and conditions of the Creative Commons Attribution (CC BY) license (http:/ / creativecommons.org/licenses/by/4.0/). 